\title{
Wear pattern on the bottom of tennis shoe after surgical repair of acute Achilles tendon rupture: 22-year follow-up
}

\author{
Akut Aşil tendonu yırtılmasının cerrahi tamiri sonrası tenis ayakkabısının tabanında \\ yıpranma paterni: 22 yıllık izlem
}

\author{
O. Şahap Atik, MD \\ Professor of Orthopedic Surgery, Turkish Joint Diseases Foundation, Ankara, Turkey
}

\begin{abstract}
In this article, we report a 67-year-old male patient who had a different wear pattern on the bottom of his tennis shoe after surgical repair of acute Achilles tendon rupture with 22-year follow-up. The wear pattern was well-matched with dynamic pedobarography. In left shoe with less total contact area and higher pressure values, there was more wear compared to right shoe.
\end{abstract}

Keywords: Achilles tendon rupture, anatomic changes, surgical repair.

Achilles tendon ruptures occur at higher rates in the middle-aged population due to age-related changes. Initiating the degenerative changes are decreasing elasticity and function of the tendon. ${ }^{[1]}$ Operative and nonoperative treatments of acute Achilles tendon ruptures, using conventional or accelerated functional rehabilitation, have some complications. ${ }^{[2,3]}$ In this article, we report a patient who had a different wear pattern on the bottom of his tennis shoe after surgical repair of acute Achilles tendon rupture in 22-year follow-up.

\section{CASE REPORT}

A 67-year-old male patient had acute left Achilles tendon rupture 22 years before. He had surgical treatment with modified Bosworth technique. There was no complication in the short-term period. The
$\ddot{O} Z$

Bu yazıda, 22 yıllık izlem ile akut Aşil tendonu yırtılmasının cerrahi tamiri sonrası tenis ayakkabısının tabanında farklı bir yıpranma paterni olan 67 yaşında bir erkek hasta sunuldu. Yıpranma paterni dinamik pedobarografi ile uyumlu idi. Daha az total temas alanı ve daha yüksek basınç değerleri olan sol ayakkabıda sağ ayakkabıya kıyasla daha fazla yıpranma vardi.

Anahtar sözcükler: Aşil tendonu yırtılması, anatomik değişiklikler, cerrahi tamir.

only complaint was a feeling that the size of the left foot was smaller than the right side. The last physical examination at 22 years revealed no significant difference between two sides for walking, running, climbing, rising on heels, rising on toes, single-limb stance, laxity of the ankle joint, or range of motion in ankle.

However, there were structural changes in 15-year follow-up. ${ }^{[4]}$ Dynamic pedobarography (EMED-SF, Novel, Munich, Germany) demonstrated that the left foot had less total contact area, higher pressure values, lower arch index, more laterally located center of pressure (COP), and higher medial arch than the right foot (Table 1, Figure 1). ${ }^{[4]}$

The patient was a frequent tennis player; he was playing tennis three times a week. In last two 
TABLE I

Dynamic pedobarography results for right and left feet

\begin{tabular}{lcc}
\hline & Right foot & Left foot \\
\hline Total contact area $\left(\mathrm{cm}^{2}\right)$ & 175.5 & 171.5 \\
Peak pressure value $\left(\mathrm{n} / \mathrm{cm}^{2}\right)$ & & \\
$\quad$ Forefoot & 31 & 40 \\
$\quad$ Midfoot & 10.5 & 14.5 \\
$\quad$ Hindfoot & 31 & 34 \\
Arch index & 0.33 & 0.26 \\
Mediolateral area difference with the & & \\
reference of center of pressure $\left(\mathrm{cm}^{2}\right)$ & 2.12 & 3.19 \\
\hline
\end{tabular}

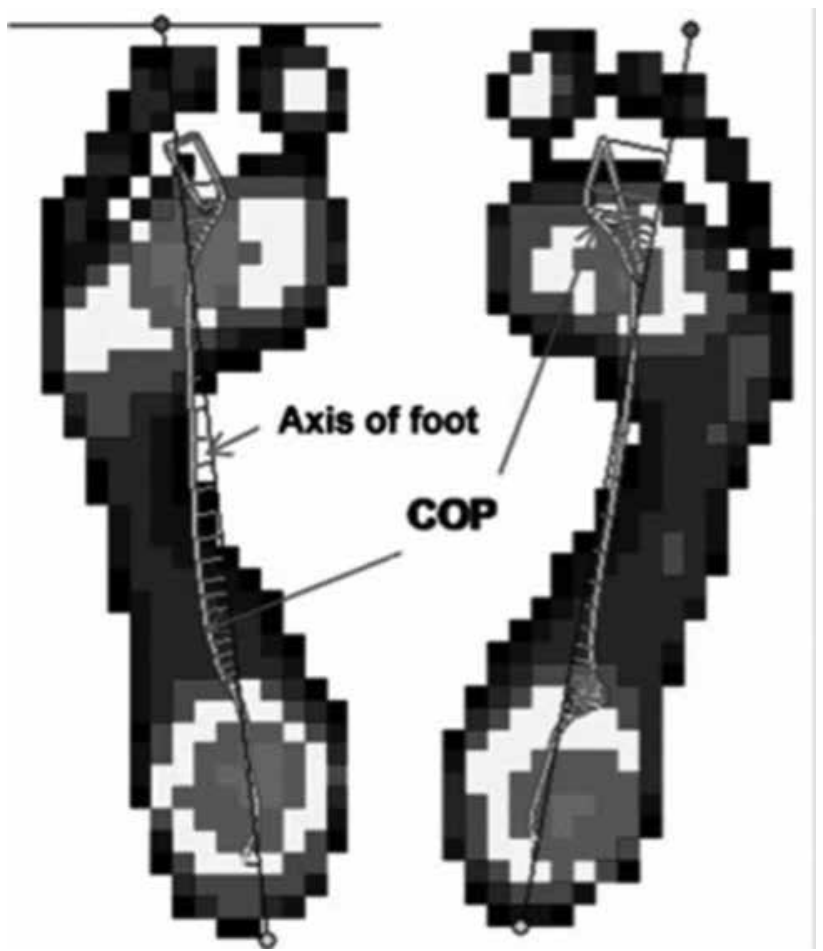

Figure 1. Dynamic pedobarography demonstrated that left foot had less total contact area, higher pressure values, lower arch index, more laterally located center of pressure (COP), and higher medial arch than right foot.

years, he recognized a different wear pattern on the bottom of his tennis shoe. The wear pattern was well-matched with dynamic pedobarography. In left shoe with less total contact area and higher pressure values, there was more wear compared to right shoe (Figure 2). A written informed consent was obtained from the patient.

\section{DISCUSSION}

Many complications have been reported after both nonoperative and operative techniques for

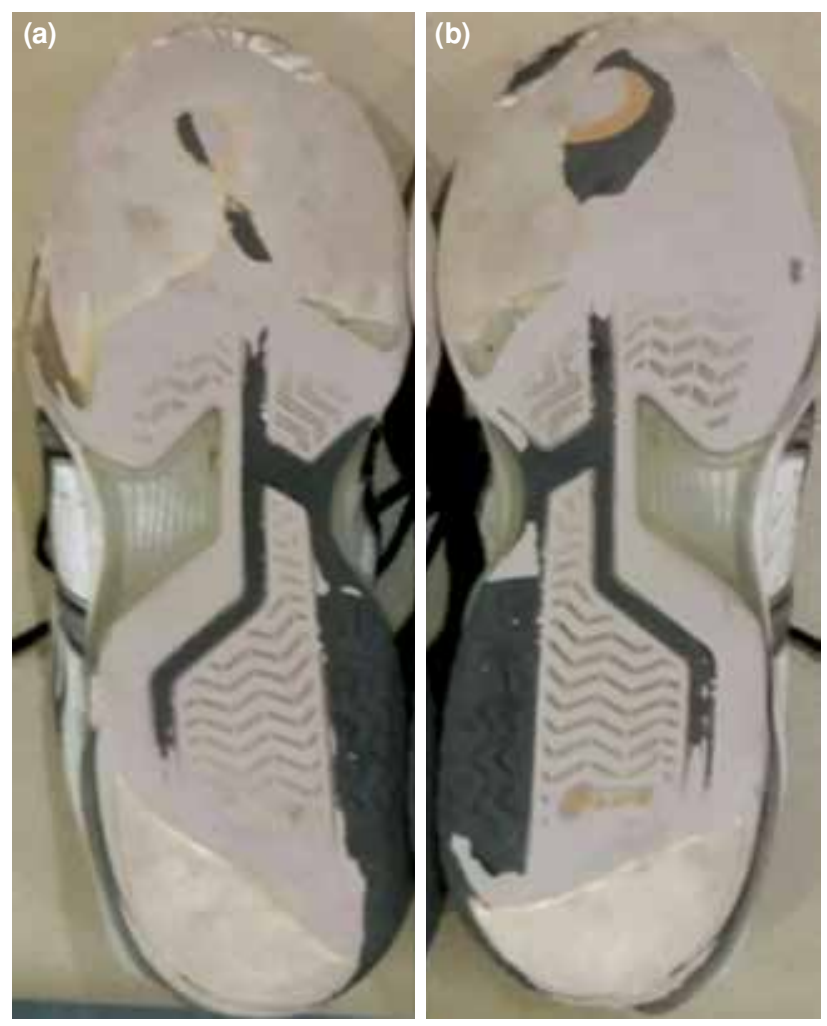

Figure 2. (a, b) Wear pattern on bottom of right and left tennis shoes. In left shoe with less total contact area and higher pressure values, there was more wear compared to right shoe.

the treatment of Achilles tendon ruptures. ${ }^{[4]}$ In our case, the left foot had less total contact area, higher pressure values, lower arch index, more laterally located COP, and higher medial arch than the right. These structural changes caused a different wear pattern in the tennis shoe. Further studies with more patients are necessary to find out the biomechanics of this pathology that orthopedic surgeons should be aware of and inform their patients accordingly.

\section{Declaration of conflicting interests}

The authors declared no conflicts of interest with respect to the authorship and/or publication of this article.

\section{Funding}

The authors received no financial support for the research and/or authorship of this article.

\section{REFERENCES}

1. Oktem H, Calgüner E, Erdoğan D, Elmas C, Gözil R, Kadioğlu D, et al. Age-related changes in light microscopy with Sirius red technique in rat Achilles tendon. [Article in Turkish] Eklem Hastalik Cerrahisi 2010;21:50-5.

2. Metzl JA, Ahmad CS, Levine WN. The ruptured Achilles tendon: operative and non-operative treatment options. Curr Rev Musculoskelet Med 2008;1:161-4. 
3. Molloy A, Wood EV. Complications of the treatment of Achilles tendon ruptures. Foot Ankle Clin 2009;14:74559.
4. Atik OS, Bölükbaşı S, Kanatlı U. Does surgical repair of acute Achilles tendon rupture cause structural changes on 15-year follow-up? Eklem Hastalik Cerrahisi 2011;22:54-5. 